\title{
The role of agroforestry in building livelihood resilience to floods and drought in semiarid Kenya
}

\author{
Amy Quandt $^{1,2}$, Henry Neufeldt $^{3}$ and $\underline{\text { J. Terrence McCabe }}^{4}$
}

\begin{abstract}
Climate change may create serious problems for farmers by increasing precipitation variability and drought and flood events. Understanding how to build livelihood resilience to these effects is a pressing need. Agroforestry is one potential solution. Although many people intuitively link agroforestry with livelihood resilience to floods and drought, little comprehensive empirical evidence exists. Here, we strive to answer the call for more empirical evidence by drawing on field work in Isiolo County, Kenya to ask the research question: How does agroforestry help smallholder farmers build livelihood resilience to floods and drought? We used a mixed-methods approach that included 20 qualitative case study households and 338 quantitative household surveys. Our major findings are: (1) practicing agroforestry can influence perceptions of floods and drought, (2) specific environmental and livelihood benefits of agroforestry contribute to livelihood resilience, and (3) agroforestry directly and indirectly builds livelihood resilience to floods and drought. Identifying potential climate change adaptation strategies is crucial for smallholder farmers. Our research indicates that agroforestry is one promising option.
\end{abstract}

Key Words: agroforestry; climate change; drought; flood; Kenya; resilience; sustainable livelihoods

\section{INTRODUCTION}

Climate change is projected to increase global temperatures, which could affect the agricultural growing season and increase drought (Noble et al. 2014). Understanding how to build livelihood resilience to the impacts of climate change such as floods and droughts is important because livelihood systems must adapt to global and local changes. Agroforestry may be able to build livelihood resilience to the impacts of climate change for smallholder farmers. Although there has been significant research about agroforestry technologies, less is known about how agroforestry contributes to building livelihood resilience (Thorlakson and Neufeldt 2012). There has been a call from the academic and development communities for more empirical evidence about the links between agroforestry and livelihood resilience to climate change (Lin 2011, Thorlakson and Neufeldt 2012). Nobel Peace Prize Laureate Wangari Maathai states, "Trees have an important role to play not only in climate change mitigation but also in reducing vulnerability to climate related risks" (Maathai 2012:5). Here, we strive to answer the call for more empirical evidence by drawing on field work in Isiolo County, Kenya to address the research question: How does agroforestry help smallholder farmers build livelihood resilience to floods and droughts? In examining this research question, our major objectives are to understand: (1) any relationships between practicing agroforestry and perceptions of floods and droughts, (2) specific agroforestry benefits that contribute to livelihood resilience, and (3) if and how agroforestry directly and indirectly builds livelihood resilience to floods and droughts.

\section{Theoretical framework}

We draw from the theoretical framework of resilience thinking (Holling 1973) and the concept of livelihood resilience (Tanner et al.2015). Walker and Salt (2006) define resilience as the capacity of a system to absorb disturbance and still retain its basic function and structure. Resilience centers on the questions of "resilience of what, to what, and for whom?" (Brown 2014). There are two main aims of building resilience: to prevent the system from moving to an undesired, alternative regime in the face of change; and to nurture and preserve the components of the system that build resilience and allow the system to renew and reorganize after a disturbance (Walker et al. 2002). Broadly, the concept of resilience is a promising tool for exploring adaptive changes toward sustainability because it provides a way for analyzing how to maintain stability in the face of change (Berkes et al. 2002) Since the late 1990s, resilience thinking has gained prominence in international development and policy communities (Berkes et al. 2002, Jones and Tanner 2015, Walsch-Dilley et al. 2016).

However, although resilience thinking has been praised by some, it has also attracted criticisms. For example, resilience thinking is often highly context specific, which challenges its implementation within policy (Cooper and Wheeler 2015), and it is often focused on natural systems, downplaying the importance of the social or political side of social-ecological systems (Brown 2014). One response to these criticisms has been the development of a livelihood perspective in resilience thinking. Tanner et al. (2015:23) propose that the lens of resilience "requires greater attention to human livelihoods if it is to address the limits of adaptation strategies and the development needs of the poorest and most vulnerable people." Livelihood resilience is defined by Tanner et al. (2015:23) as "the capacity of all people across generations to sustain and improve their livelihood opportunities and well-being despite environmental, economic, social, and political disturbances." A livelihood approach expands the understanding of resilience to acknowledge that people's circumstances, cultures, values, and perceptions affect their ability to adapt (Enns and Bersaglio 2015, Tanner et al. 2015). Building livelihood resilience means that a given household's livelihood strategies are better prepared to manage the effects of shocks, navigate uncertainty, and adapt to changing conditions (Marschke and Berkes 2006, Ngigi et al. 2015).

${ }^{1}$ Jornada Experimental Range, New Mexico State University, ${ }^{2}$ Sustainability Innovations Lab at Colorado, University of Colorado Boulder, ${ }^{3}$ World Agroforestry Centre, Climate Change Unit, ${ }^{4}$ Institute of Behavioral Science, Department of Anthropology, University of Colorado Boulder 


\section{Sustainable livelihoods approach to measuring livelihood resilience to floods and droughts}

Livelihood resilience is difficult to measure directly, and many authors instead use surrogates or indicators of resilience (Carpenter et al. 2001, Nelson and Stathers 2009, Leslie and McCabe 2013). Nonetheless, there is no standard protocol for determining indicators of resilience. Here, we propose that using the sustainable livelihoods approach provides one innovative method for determining indicators of resilience and has been used in a handful of studies (Elasha et al. 2005, Erenstein et al. 2010, Thulstrup 2015). As stated by Thulstrup (2015), sustainable livelihoods are a key component of resilience and vice versa. The sustainable livelihoods approach emphasizes that livelihoods should be considered in terms of people's access to capital assets, the ways in which people combine these capital assets to create livelihoods, and how people are able to enlarge their asset base through interactions with actors and institutions (Chambers and Conway 1992, Carney 1998). At the core of the sustainable livelihoods approach are the five capital assets: financial, physical, natural, human, and social. Social capital includes networks, groups, associations, and relationships of trust and reciprocity (Adger 2003). Physical capital refers to access to services and infrastructure (Adato and Meizen-Dick 2002). Human capital encompasses the skills, knowledge, education, health, and labor availability of the household (Tacoli 1999). Financial capital refers to savings, credit, remittances, and financial assets (Campbell et al. 2001, Erenstein et al. 2010). Lastly, natural capital includes access to environmental services and resources (Campbell et al. 2001, Erenstein et al. 2010). Here, we organize indicators of resilience by the five livelihood capitals, ensuring that a wide diversity of indicators are included in livelihood resilience (Table 1). Furthermore, using the five livelihood capital assets is an effective way to include nonmonetary measures of resilience (Rakodi 1999, Lebel et al. 2006).

\section{Agroforestry and livelihood resilience to climate change}

Climate models for Africa predict a $3-4^{\circ} \mathrm{C}$ increase in temperatures by the end of the 21 st century, roughly 1.5 times the global mean increase (Bryan et al. 2013). With temperature increases at this magnitude, climate change will have negative effects on agriculture, and agriculture in semi-arid regions is particularly vulnerable (Porter et al. 2014). Additionally, climate change is expected to cause an increase in the number and strength of natural hazards such as floods and drought (Porter et al. 2014), and these effects are most severe at the local scale, where livelihoods are affected (Shaw 2006). Households must adapt by building livelihood resilience to the impacts of climate change (Speranza 2013). Adopting agroforestry has been proposed as one livelihood activity that can help build livelihood resilience to floods and droughts (Kandji et al. 2006, Verchot et al. 2007, Garrity et al. 2010, Lin 2011, Thorlakson and Neufeldt 2012, Bryan et al 2013, Simelton et al. 2015).

Agroforestry is a multifaceted, ecologically based, natural resource management system that, through the integration of trees on farms and within the agricultural landscape, is believed to diversify and sustain production for increased social, economic, and environmental benefits (Franzel and Scherr 2002, Schroth et al. 2004). Agroforestry practices involve combinations of trees, crops, and animals in various spatial arrangements or temporal sequences on the landscape (Rocheleau et al. 1988, Sinclair 1999).
Some of the ecological characteristics of agroforestry species make them resilient to floods and droughts, including deep root systems that are able to use a greater soil volume for water and nutrients (Kandji et al. 2006, Verchot et al. 2007). Shade trees can produce microclimates that buffer temperature fluctuations (Lin 2007), which in turn can reduce evapotranspiration. Further, trees have the ability to buffer crops from storms (Philpott et al. 2008).

Table 1. List of household survey livelihood resilience indicators.

\begin{tabular}{|c|c|}
\hline Asset & Quantitative indicator (independent variable) \\
\hline $\begin{array}{l}\text { Financial } \\
\text { capital }\end{array}$ & $\begin{array}{l}\text { Salaried job (yes or no) } \\
\text { Access to a bank account (yes or no) } \\
\text { Remittances (yes or no) } \\
\text { Household belongings (number of belongings; five } \\
\text { response variables) } \\
\text { Livestock (number of livestock; six response variables) } \\
\text { Size of farmland (number of acres) } \\
\text { Ownership of farm equipment (own, rent, or borrow } \\
\text { pieces of equipment; three response variables) }\end{array}$ \\
\hline $\begin{array}{l}\text { Human } \\
\text { capital }\end{array}$ & $\begin{array}{l}\text { Labor availability (number of household members } \\
\text { between } 18 \text { and } 55 \text { ) } \\
\text { Education (level of education of respondent; eight } \\
\text { response variables) } \\
\text { General health of family (scale of poor to good; five } \\
\text { response variables) } \\
\text { Health problems' effect on ability to practice livelihoods } \\
\text { (scale of no to very much; four response variables) }\end{array}$ \\
\hline $\begin{array}{l}\text { Social } \\
\text { capital }\end{array}$ & $\begin{array}{l}\text { Family living nearby (yes/no, distance; four response } \\
\text { variables) } \\
\text { Political influence or power (scale of none to a lot; four } \\
\text { response variables) } \\
\text { Participation in groups (number of groups; } 12 \text { response } \\
\text { variables) } \\
\text { Participation in agriculture or tree planting group (yes or } \\
\text { no) } \\
\text { Strength of relationship with neighbors (number of } \\
\text { activities done with neighbors; } 10 \text { total response } \\
\text { variables) }\end{array}$ \\
\hline $\begin{array}{l}\text { Physical } \\
\text { capital }\end{array}$ & $\begin{array}{l}\text { Normal and rainy season road conditions (scale of good } \\
\text { to bad; five response variables) } \\
\text { Presence of facilities (schools, hospitals, etc.) within } 3 \mathrm{~km} \\
\text { of home (11 response variables) } \\
\text { Access to irrigation schemes (yes or no) } \\
\text { Ownership of farming equipment (own, rent, or borrow } \\
\text { pieces of equipment; three response variables) }\end{array}$ \\
\hline $\begin{array}{l}\text { Natural } \\
\text { capital }\end{array}$ & $\begin{array}{l}\text { Size of farmland (number of acres) } \\
\text { Own farmland (yes or no) } \\
\text { Diversity of farm crops (number of different crops } \\
\text { planted) } \\
\text { Livestock (number of livestock; six response variables) } \\
\text { Soil erosion (rank of severity of soil erosion on farm; } \\
\text { four response variables) }\end{array}$ \\
\hline
\end{tabular}

There is some evidence that agroforestry is already being adopted by farmers to adapt to the effects of climate change (Thorlakson and Neufeldt 2012, Bryan et al. 2013, Simelton et al. 2015). Thorlakson and Neufeldt (2012) report that some farmers in Kenya rely on fruit trees for income during floods when other crops are washed away; during drought, farmers sold fuel wood and timber to purchase food. In Kenya, Bryan et al. (2013) found that farmers desired to invest in agroforestry to adapt to climate change. Lastly, in Ethiopia, Enset ventricosum, a droughtresistant, banana-like plant, is used as a staple drought food for 
10 million people (Brandt et al. 1997). These studies begin to provide evidence of the role of agroforestry in building livelihood resilience to floods and droughts. However, none take a comprehensive livelihood resilience approach to linking agroforestry with resilience to floods and droughts, as we do here.

\section{METHODS}

A mixed-methods approach was used because it allows addressing more complicated research questions and collecting "a richer and stronger array of evidence than can be accomplished by any single method alone" (Yin 2013:66). Therefore, we drew on complimentary qualitative and quantitative data to address the research question holistically. Field work took place between July 2014 and July 2015. A total of 338 quantitative household surveys were conducted from March to May 2015; 152 in Kinna and 187 in Burat, Kenya. An additional 20 qualitative household case studies were conducted in Burat $(N=13)$ and Kinna $(N=7)$. All households that participated practiced agriculture, but not all practiced agroforestry. Agroforestry was measured in a variety of ways: if a household had planted trees or not, number of trees, diversity of tree species, and tree density (number of trees per unit area). The World Agroforestry Centre (2017) defines the word tree inclusively and broadly, referring to trees and shrubs, woody perennials, palms, and bamboo. Thus, we use this definition to include papaya and banana as tree species in this research.

\section{Study area}

Research was conducted in the communities of Burat and Kinna in Isiolo County, Kenya (Fig. 1). The population of the agricultural area of Burat is approximately 2500 (Chief of Burat, personal communication, 2014), which lies along the banks of the Isiolo and Aye Nakore rivers approximately $3 \mathrm{~km}$ from Isiolo Town. Turkana, Meru, Somali, Samburu, and Borana ethnic groups live in Burat (Boye and Kaarhus 2011). In contrast, Kinna is largely Borana and includes approximately 900 households (Jillo et al. 2006). The climate in Isiolo County is changing, and since the 1970s, the long rains have declined by $>100 \mathrm{~mm}$ and there has been a warming of $>1{ }^{\circ} \mathrm{C}$ (Funk et al. 2010). Isiolo County is prone to flooding during El Niño years, the most recent occurring in 1997. It is important to mention that although some households were technically within protected areas, these conservancies in reality do not have much impact on their life or livelihoods. Also, access to markets varied among households based on proximity to urban centers (Isiolo and Kinna Town), and this was accounted for in measuring livelihood resilience (see Table 1).

Livelihoods in Isiolo County have changed in the past 50 years. In Kinna, Borana have been adopting agriculture as a coping strategy for livestock-poor households (Otuoma et al. 2009). Massive livestock losses are attributed to the shifta war in the 1960s (Hogg 1983) and droughts in the 1970s and 1980s (Helland 1998). The response of the government after the shifta war ended was to establish small-scale irrigation schemes (Hogg 1989). According to Kinna elders, the irrigation scheme was dug by the government in 1969 (personal communication). Agriculture began in Burat when Meru began moving into the area and claiming farmland in the late 1970s (personal communication).

\section{Data collection}

The household surveys represent statistically representative sample sizes of households practicing agriculture in Kinna and
Burat. The survey focused on indicators of resilience (Table 1; see Data analysis for details), livelihood activities, and agroforestry during floods and droughts. Surveys were conducted by enumerators who participated in two days of training. Surveys were conducted in Swahili or Borana, based on the language ability of the respondents. At each household, the male or female household head took part in the survey based on who was available and willing to participate. Enumerators surveyed every other household along a transect, and if no one was available, enumerators surveyed the next available household. Global positioning system coordinates were taken at each survey household.

Fig. 1. Map indicating the locations of the study areas.

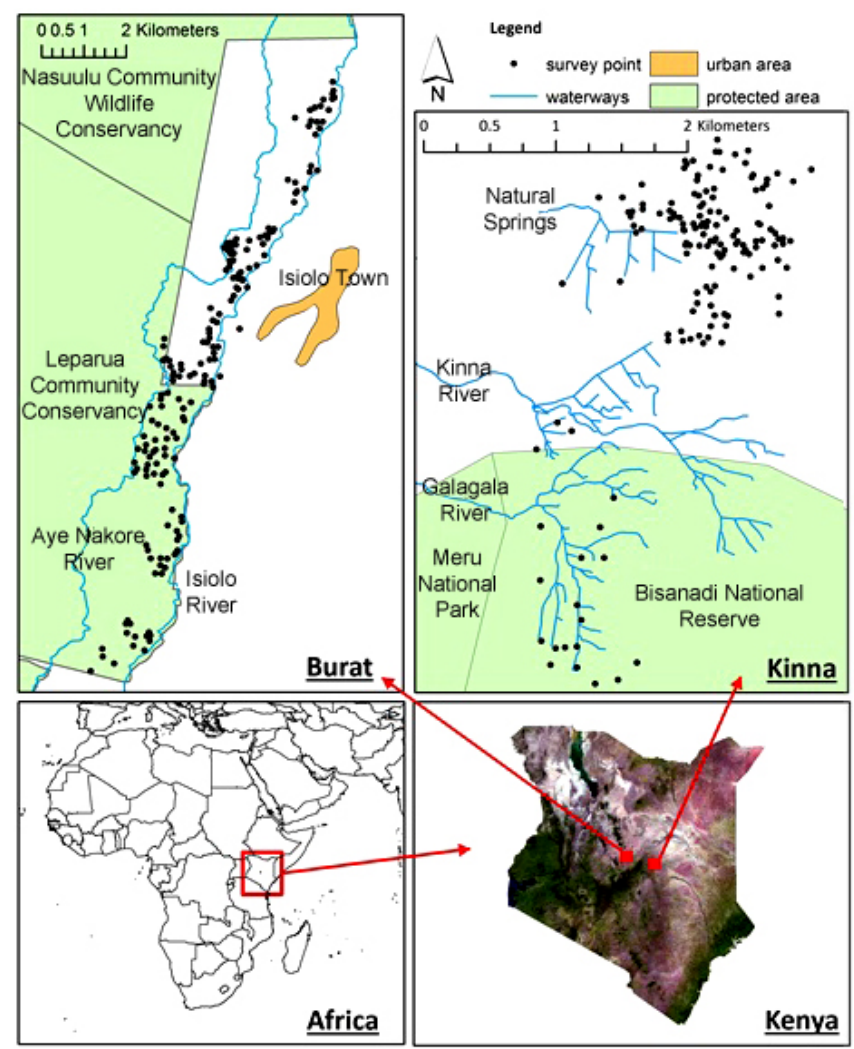

The qualitative household case studies were selected through combined convenience and respondent-driven sampling (Bernard 2011). Each household was interviewed three times, and when possible, both male and female household heads were interviewed. The aim of the first interview was to gather information about household livelihoods. Each household was then interviewed about floods during the rainy season (April-May 2015) and about drought during the dry season (August-October 2014). These interviews were in-depth, unstructured, and while they were centered around a clear plan of six to eight topics, they also allowed people to open up and express themselves in their own terms (Bernard 2011). The purpose of these interviews was to capture what Bernard (2011) calls the "lived experience" of humans. Recorded interviews were conducted in Swahili and later transcribed verbatim in Swahili using Phillips SpeechExec Transcribe 7.1 software by a Swahili speaker. 


\section{Data analysis}

The quantitative survey data were analyzed using Microsoft Excel and STATA IC13 software. Statistical tests such as Pearson's $\chi^{2}$, zero-truncated negative binomial regression models, and nonparametric tests such as Kruskal-Wallis tests were conducted to test for statistical significance of the results. These methods were used because they compare the means for several groups to the association between a quantitative response variable or categorical explanatory variable (Agresti and Finlay 2009). Furthermore, we drew from the five livelihood capital assets of the sustainable livelihoods approach to create measurable indicators of livelihood resilience (Table 1). Indicators were chosen based on the literature review of livelihoods resilience in Isiolo, Kenya and previous research experience in the research sites. Resilience is a key component of sustainable livelihoods, and similar approaches to measuring resilience have been used previously (Campbell et al. 2001, Erenstein et al. 2010, Thulstrup 2015). In previous work, Erenstein et al. (2010) used the five capital assets to organize indicators of resilience and compare asset scores between different types of households, whereas Campbell et al. (2001) organized indicators of resilience based on the five livelihood capital assets and then discussed the benefits of creating simple composite indices by aggregating the scores of individual indicators. Using those works as a guide, we gave the variety of answers for each indicator in the survey a score on a scale from 0 (worst, less desirable) to 1 (best, more desirable). Some indicators were bimodal ( 0 or 1$)$, whereas others were multimodal and included a range of scores from 0 to 1 based on the number of answer choices (for example, Likert scales with five choices). For each survey household, a simple, unweighted, composite index was calculated as the average of the indicator values for each livelihood capital.

The qualitative household case study interviews were coded using QSR Nvivo10 software with the text in Swahili to retain its original meaning. The first author is fluent in Swahili and led the transcribing and coding process and also translated the quotations used throughout into English. Codes were developed from the academic literature, the discussion topics, and themes that emerged during the research process. The different sources of data (qualitative, quantitative, and ecological) were compared and contrasted to triangulate results in an iterative process. Here, we omit names from all quotations.

\section{RESULTS}

The results are based on our three major objectives. Table 2 provides some context about household characteristics of survey respondents who practice agroforestry and those who do not in Kinna and Burat.

\section{Perceptions of flood and drought}

To understand relationships between practicing agroforestry and perceptions of floods and drought, survey respondents were asked about their perceptions of changes in flood and drought frequency and severity over the previous 10 years. Households overwhelmingly agreed that floods are becoming less frequent (154 respondents), less severe (151 respondents), and that the timing of the rains has become less predictable (171 respondents). Only 195 survey respondents had experienced flooding on their land, and thus, only these 195 respondents were asked questions about floods.
Perceptions of changes in drought (Fig. 2) varied between communities and households that did and did not practice agroforestry. In Kinna, responses did not vary between households with and without agroforestry. However, for Burat there was a correlation between practicing agroforestry and perception of drought $\left(\chi^{2}=13.7896, P<0.01\right)$. Households practicing agroforestry largely responded that droughts were less frequent (64 respondents), whereas most households (46 respondents) without agroforestry stated the opposite. The number of trees, tree diversity, tree density, livelihood capital scores, and ethnic group do not explain this trend because they were not significantly correlated with perceptions of drought.

Fig. 2. Household perception of changes in the frequency of drought over the previous 10 years based on the community and whether a household practices agroforestry.

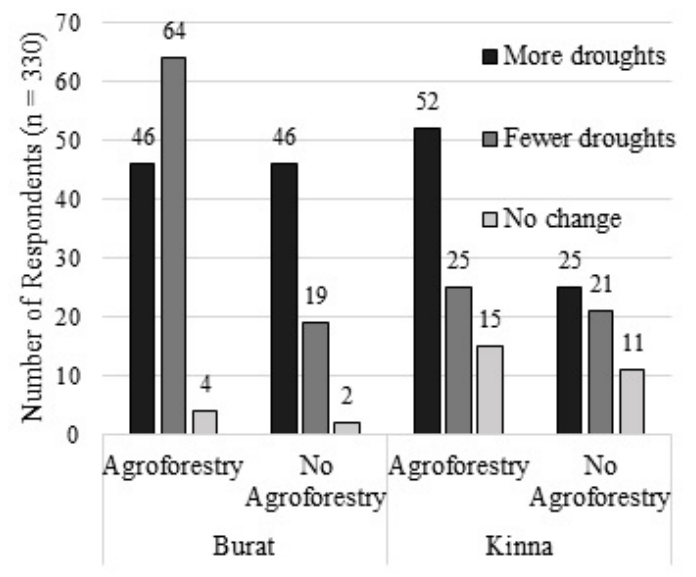

The most likely explanation for this result is the different histories behind agroforestry in Kinna and Burat (household case study interviews) and the differing definitions of drought from the survey respondents (Fig. 3). Many respondents (109) in Burat discussed drought in terms of the effects of drought (i.e., livestock death, food security issues, etc.), whereas in Kinna, respondents discussed drought in terms of a lack of rainfall (Fig. 3; zerotruncated negative binomial regression model, $P<0.01$ ). Furthermore, in the household case study interviews, interviewees indicated that the widespread adoption of agroforestry has been much more recent in Burat than in Kinna. Thus, survey respondents in Burat, who define drought in terms of effects, may not feel the effects of drought as much as they did 10 years previously, in part because of increased adoption of agroforestry and the benefits agroforestry provides. As explained by a female farmer in Burat, "... for others [drought] is there... for me, drought is not very bad. You see, now I harvest at least a little, it is not that bad. But for others there is drought."

\section{Agroforestry benefits during floods and drought}

What are the specific agroforestry benefits that contribute to livelihood resilience during drought and floods? According to survey respondents, the top benefits during both drought and floods are shade and fruit for sales and household consumption 
Table 2. Summary of household characteristics (mean and standard deviation).

\begin{tabular}{|c|c|c|c|c|c|}
\hline \multirow[b]{2}{*}{ Characteristic } & \multicolumn{2}{|c|}{ Burat, Kenya } & \multicolumn{2}{|c|}{ Kinna, Kenya } & \multirow[b]{2}{*}{ Combined } \\
\hline & Agroforestry & No agroforestry & Agroforestry & No agroforestry & \\
\hline Household size (number of people) & $7.4(3.9)^{*}$ & $5.9(2.7)^{*}$ & $6.6(2.3)$ & $7.2(2.4)$ & $6.8(3.1)$ \\
\hline Age of respondent (years) & $44.5(16.3)$ & $40.7(13.4)$ & $45.0(15.7)$ & $42.8(15.8)$ & $43.6(15.5)$ \\
\hline $\begin{array}{l}\text { Respondent's length of time living in } \\
\text { the area (years) }\end{array}$ & $31.7(15.4)^{* *}$ & $22.8(14.9)^{* *}$ & $29.8(16.6)$ & $28.5(17.9)$ & $28.8(16.4)$ \\
\hline $\begin{array}{l}\text { Access to irrigation (yes }=1, \text { no }=0 ; \\
\text { ratio) }\end{array}$ & $0.84(0.37)^{*}$ & $0.72(0.45)^{*}$ & $0.97(0.18)^{*}$ & $0.86(0.35)^{*}$ & $0.86(0.35)$ \\
\hline $\begin{array}{l}\text { Importance of irrigation (scale of } 1= \\
\text { not important to } 4=\text { very important) }\end{array}$ & $3.69(0.82)$ & $3.50(0.95)$ & $3.94(0.35)$ & $3.88(0.43)$ & $3.77(0.69)$ \\
\hline Number of different crops planted & $8.2(4.8)^{*}$ & $6.4(4.1)^{*}$ & $5.2(2.7)^{* *}$ & $3.8(2.6)^{* *}$ & $6.2(4.1)$ \\
\hline $\begin{array}{l}\text { Number of months that crops fed the } \\
\text { household in the past year }\end{array}$ & $5.7(4.5)^{* *}$ & $3.9(3.6)^{* *}$ & $3.5(2.3)$ & $3.3(3.0)$ & $4.3(3.7)$ \\
\hline $\begin{array}{l}\text { Household livelihoods affected by } \\
\text { floods (yes }=1, \text { no }=0 ; \text { ratio) }\end{array}$ & $0.54(0.5)$ & $0.52(0.5)$ & $0.72(0.45)^{* *}$ & $0.44(0.5)^{* *}$ & $0.57(0.5)$ \\
\hline Number of households & 118 & 68 & 93 & 59 & 338 \\
\hline
\end{tabular}

(Fig. 4). Households were able to name multiple benefits of trees; households that have not planted trees are not included. We also broke down the benefits of agroforestry during floods and droughts by specific tree species as discussed by the household case study participants for trees that were named $>10$ times (Table 3). Case study interviewees freely listed tree species as well as reasons why that specific tree does well during drought or floods. For floods, mango trees were named repeatedly as trees that provide multiple benefits, including income and food. An elderly female farmer in Kinna reported, "I depend on selling these mangos for food during floods." Environmental benefits were also important, as discussed by a male farmer in Burat, who said, "[by] planting trees in a line, it prevents the soil from being swept away by water." During drought, mango, papaya, and banana were listed as being the most important tree species. As a male farmer from Burat explained about mango trees, "Their roots travel far, trees are able to get water from deep down." Papaya and banana were reported as beneficial during drought because they produce fruit year round. However, they do need to be watered occasionally.

Fig. 3. Definition of drought by survey respondents in Kinna and Burat, Kenya. These responses were coded based on whether the respondent focused primarily on the rain or water, the impacts of drought, or both rain and impacts.

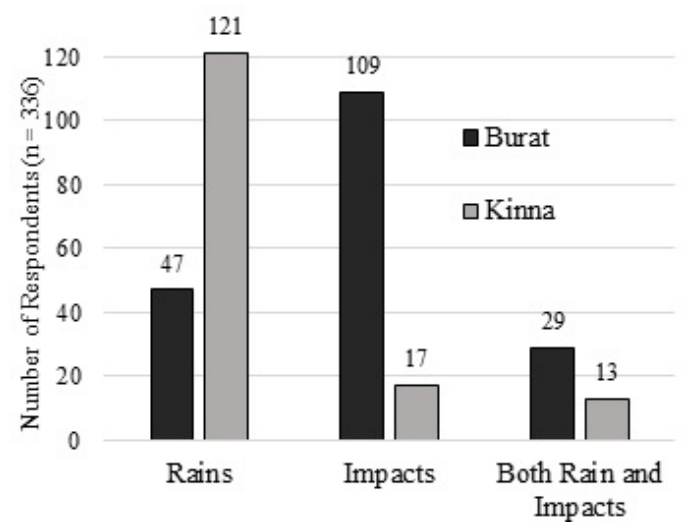

Fig. 4. Livelihood and environmental benefits of trees during drought (A) and flood (B). Data are from household surveys.

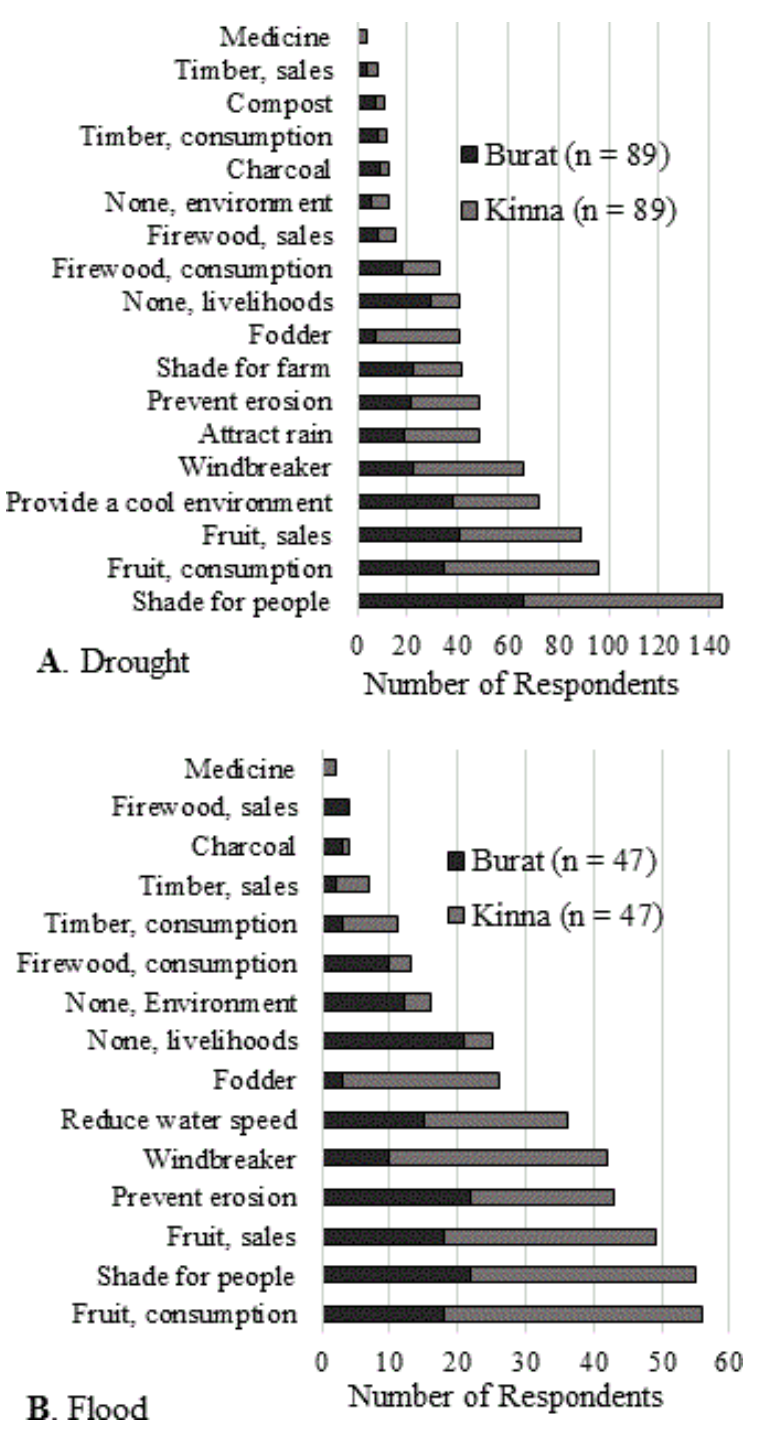


Table 3. Tree species listed and the reasons given for their performance and benefits during floods and drought. Numbers indicate the number of household case study interviewees that named that specific tree and the corresponding specific benefit. Case study interviewees freely listed tree species as well as reasons why that specific tree does well during floods or drought. Only tree species named $>10$ times are listed.

\begin{tabular}{|c|c|c|c|c|c|c|c|c|c|c|}
\hline \multirow[b]{2}{*}{ Stress } & \multirow[b]{2}{*}{ Benefit } & \multicolumn{8}{|c|}{ Tree species } & \multirow[b]{2}{*}{ Total } \\
\hline & & Acacia & Banana & Guava & Mango & Neem & Orange & Papaya & Tamarind & \\
\hline \multirow[t]{7}{*}{ Flood } & Prevent erosion & & & 3 & & 3 & & & & 6 \\
\hline & Income & & & 2 & 24 & & & & 2 & 28 \\
\hline & Food & & & 2 & 23 & & & & 2 & 27 \\
\hline & Flood resistant & & & 3 & 13 & 5 & & & 4 & 25 \\
\hline & Windbreak & & & 2 & 10 & 3 & & & 2 & 17 \\
\hline & Reduce water speed & & & 1 & 7 & 1 & & & & 9 \\
\hline & Shade & & & & 9 & 1 & & & 3 & 13 \\
\hline \multirow[t]{8}{*}{ Drought } & Use less water & 2 & 1 & 2 & 16 & 1 & 1 & 4 & 4 & 31 \\
\hline & Drought resistant & 4 & 4 & 2 & 25 & 5 & 2 & 6 & 5 & 53 \\
\hline & Income & & 8 & 4 & 39 & & 2 & 16 & 3 & 72 \\
\hline & Food & & 13 & 4 & 31 & & 2 & 27 & 2 & 79 \\
\hline & Shade & 4 & 1 & 4 & 32 & 7 & 2 & 5 & 7 & 62 \\
\hline & Fast production & & 3 & 1 & 3 & & 1 & 6 & & 14 \\
\hline & No pesticides & 2 & 2 & 1 & 6 & 2 & 1 & 1 & & 15 \\
\hline & Fodder & 4 & 2 & 2 & 5 & 1 & & & 4 & 18 \\
\hline
\end{tabular}

Survey respondents were asked how important trees are to their livelihoods during floods and droughts generally and during the 1997 El Niño flood (Table 4). Households with more trees $(P<$ $0.05)$ and a greater diversity of tree species $(P<0.05)$ were more likely to say that trees were important during drought (KruskalWallis tests between importance of trees during drought and the number of trees and diversity of tree species).

Lastly, survey respondents were asked if they had planted trees thinking that it would help them maintain their livelihoods during either floods or droughts. In both Burat and Kinna, $74 \%$ of respondents said that they had planted trees with drought in mind. In addition, $65 \%$ of respondents in Burat and $43 \%$ of respondents in Kinna said that they had planted trees with floods in mind.

\section{Agroforestry and livelihood resilience}

Data from the surveys and household case study interviews provide evidence for how agroforestry both directly and indirectly builds livelihood resilience to floods and droughts. First, household case study interviewees discussed how their livelihoods have been affected by floods and droughts and how trees mitigated those effects, both directly and indirectly (Fig. 5). Our flowcharts conceptualize how the five livelihood capital assets are affected by drought and floods and how agroforestry builds livelihood resilience to these impacts. These models were created from the household case study interviews and the literature on the five livelihood capital assets and illustrate how agroforestry directly mitigates the effects of floods and drought. For example, drought can cause livestock hunger, and agroforestry can directly moderate this effect by providing nutritious fodder for livestock (Fig. 5B). These models also illustrate how agroforestry can indirectly mitigate the effects of floods and drought to build livelihood resilience more generally. For example, from Figure $5 \mathrm{~A}$, agroforestry often provides a household with construction materials, which builds a household's financial capital (Fig. 5A). Agroforestry can also provide money for school fees, building a household's human capital (Fig. 5B). Increased levels of financial and human capital may help a household be better prepared for a disturbance such as flood or drought.

Second, the livelihood capital asset scores of each survey respondent (financial, human, social, physical, and natural) were divided into groups of respondents that ranked agroforestry as being important, a little important, somewhat important, or very important during drought, floods, and the 1997 El Niño. Only financial capital scores varied significantly between households during floods $(P<0.05)$ and the 1997 El Niño $(P<0.05$; KruskalWallis tests), but not drought (Fig. 6). The financial capital scores are based on the average of all financial indicators for each survey respondent. Those survey respondents who reported that trees are not important to them during any event had the lowest financial capital scores. This is likely because these households also planted fewer trees. For example, during floods, survey respondents who ranked agroforestry as not important had on average 12 trees, whereas all other survey respondents had on average 74 trees. This also provides evidence that the number of trees is important in linking agroforestry to livelihood resilience; more trees may equate to greater benefits. Importantly, survey respondents that ranked agroforestry as very important during drought, flood, and the 1997 El Niño had overall lower financial capital scores than households that ranked agroforestry as a little or somewhat important. This suggests that agroforestry may be most important for middle-income households. 
Fig. 5. Frameworks showing effects of floods (A) and drought (B) on five livelihood capital assets, and the benefits of trees. The depicted relationships were derived from household case study interviews. Colored bubbles represent different themes that arose during the interviews: orange $=$ drought, blue $=$ floods, green $=$ agroforestry $($ green $)$.

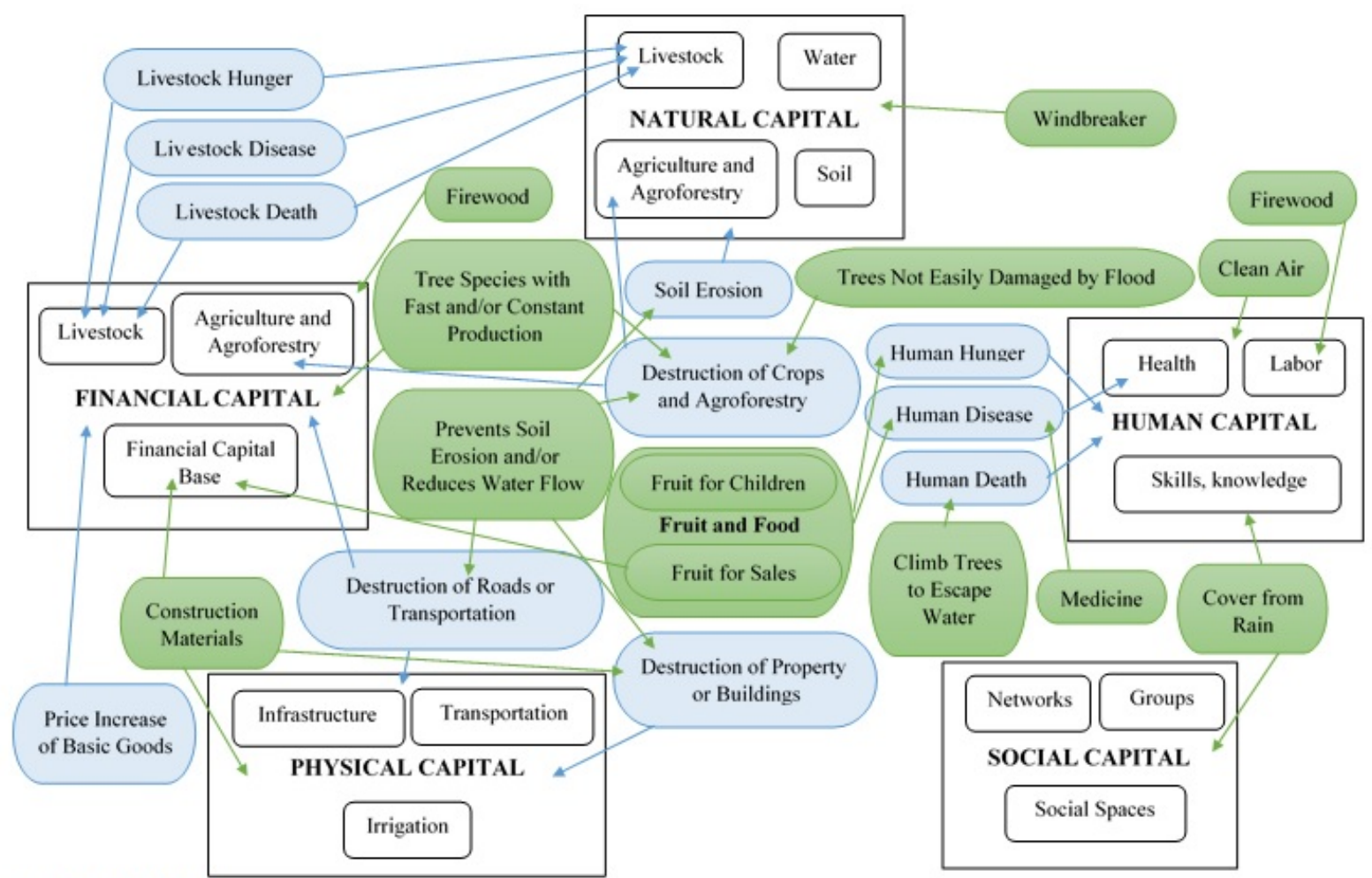

\section{A. Flood Model}

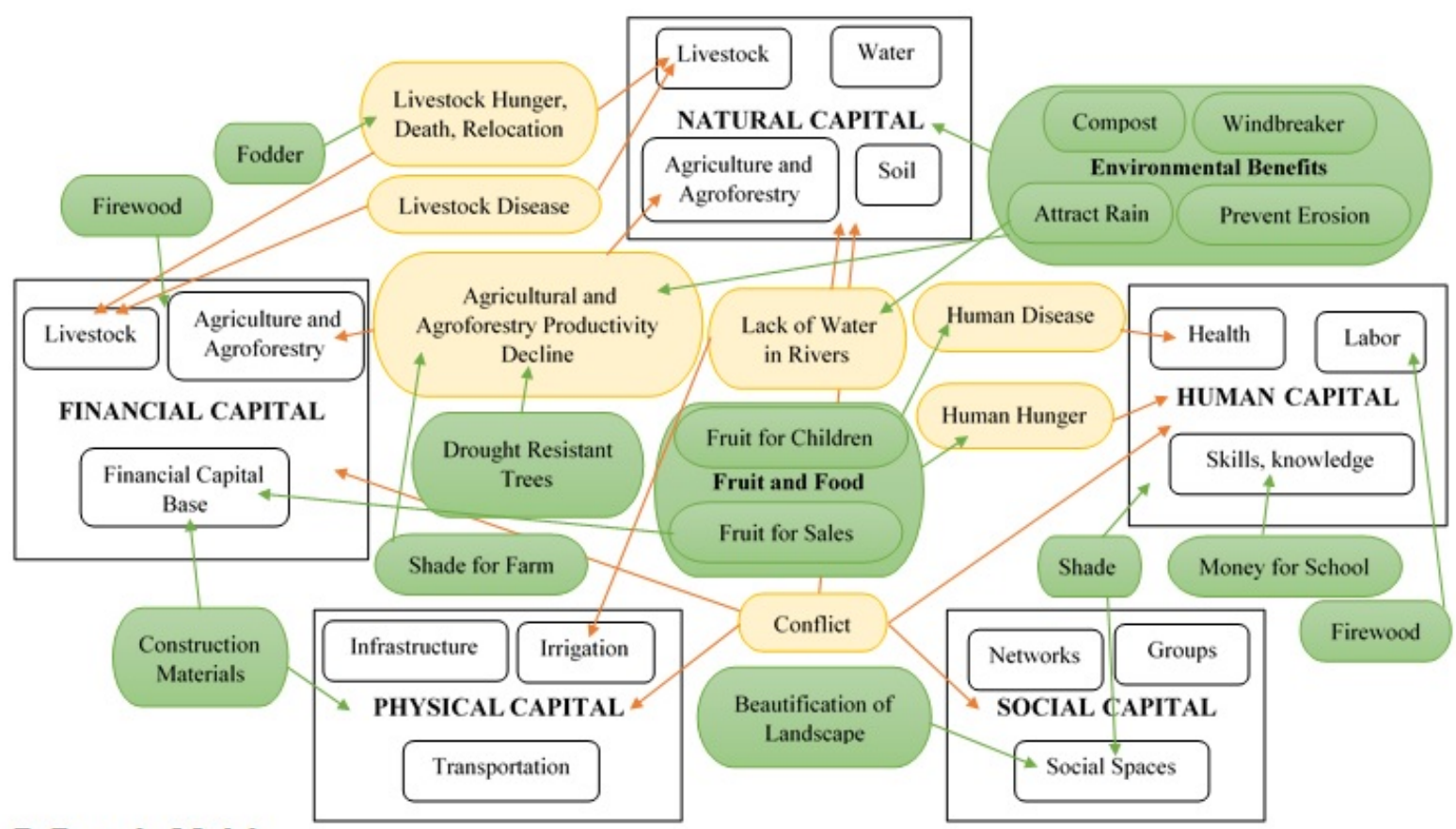

\section{B. Drought Model}


Table 4. Proportion (\%) of survey respondents who listed agroforestry as being important for the household livelihood during drought, floods, and the 1997 El Niño flooding.

\begin{tabular}{|c|c|c|c|c|c|c|c|c|c|}
\hline \multirow[b]{2}{*}{ Importance } & \multicolumn{3}{|c|}{ Drought } & \multicolumn{3}{|c|}{ Flood } & \multicolumn{3}{|c|}{ El Nino 1997} \\
\hline & Burat & Kinna & Total & Burat & Kinna & Total & Burat & Kinna & Total \\
\hline Not important & 22 & 2.3 & 12.2 & 14.6 & 2.2 & 8.6 & 19.1 & 4.4 & 11.4 \\
\hline $\begin{array}{l}\text { A little } \\
\text { important }\end{array}$ & 9.9 & 24.7 & 17.2 & 14. 6 & 28.9 & 21.5 & 11.9 & 30.4 & 21.6 \\
\hline $\begin{array}{l}\text { Somewhat } \\
\text { important }\end{array}$ & 8.8 & 18 & 13.3 & 10.4 & 8.9 & 9.7 & 11.9 & 15.2 & 13.6 \\
\hline $\begin{array}{l}\text { Very } \\
\text { important }\end{array}$ & 59.3 & 55.1 & 55.1 & 60.4 & 60 & 60.2 & 57.1 & 50 & 53.4 \\
\hline Sample size ${ }^{\dagger}$ & 91 & 89 & 180 & 48 & 45 & 93 & 42 & 45 & 88 \\
\hline Pearson $\chi^{2}$ & & & $23.07 * *$ & & & 6.39 & & & $8.05^{*}$ \\
\hline
\end{tabular}

$* P<0.05, * * P<0.01$.

${ }^{\dagger}$ Sample sizes vary because not all respondents were asked all questions. For example, these numbers exclude all households without agroforestry. Additionally, households that had never experienced flooding were not asked flood questions.

Fig. 6. Financial capital based on rankings by survey households of the importance of trees during drought, flood, and the 1997 El Niño.

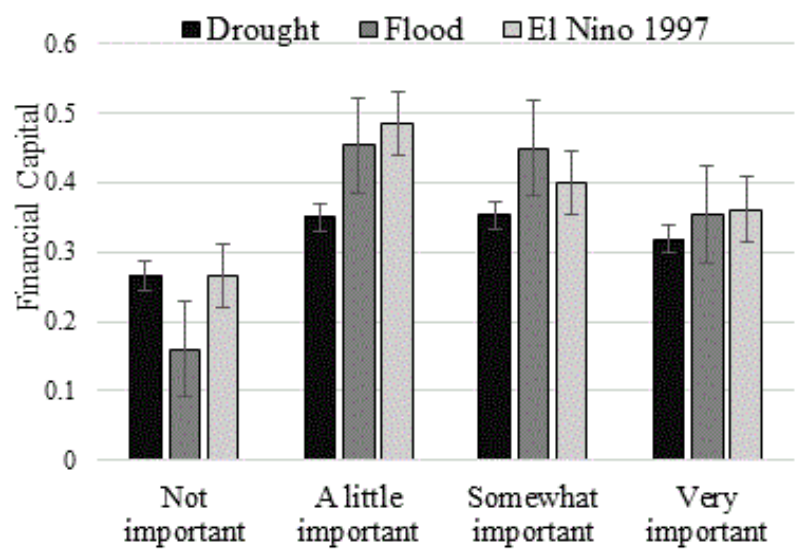

\section{DISCUSSION}

In answering the question of how agroforestry can build livelihood resilience to floods and droughts, the results highlight three major objectives, which we discuss next.

\section{Agroforestry and perceptions of drought and floods}

The results show that practicing agroforestry may change how drought is perceived and felt by a household. Perceptions of drought are important because households often act on their perceptions, regardless of scientific data (Meze-Hausken 2004). Additionally, a person's perceptions may affect their ability to adapt and build livelihood resilience (Enns and Bersaglio 2015, Tanner et al. 2015). Rao et al. (2011) found that farmers' ability to discern long-term trends in climate is often subjective because of the complex interactions between climate and other factors, including soil fertility, land use change, and local economic conditions. Perception and definitions of drought can be influenced by local biophysical, social, cultural, economic, and political conditions (Slegers 2008). In our research, the benefits provided by agroforestry may have played a role in perceptions of drought when comparing current conditions to those of 10 years previously. For example, before planting trees, a farmer might have struggled to produce crops during drought, whereas after planting trees, he or she is able to sell fruit and firewood. Whereas the farmer originally did not have an income during drought, he or she now has at least something small to fall back on, causing the effects of drought to seem less severe. Understanding this interplay between practicing agroforestry and perception of drought is important for any resilience-building development project because people act on their perceptions.

Agroforestry benefits during flood and drought

To help farmers build livelihood resilience to floods and drought, agroforestry needs to provide benefits during these events. Farmers recognized the scientifically documented environmental benefits of trees during floods (for example, see Rocheleau et al. 1988, Franzel and Scherr 2002). Indeed, environmental benefits comprised half of the listed benefits of trees during floods. During drought, agroforestry's environmental benefits can be enhanced by its ecological characteristics (Lin 2007). For example, some tree species can maintain production during drier years because their deep root systems are able to use a greater soil volume to obtain water and nutrients (Verchot et al. 2007). This characteristic makes certain tree species more resilient to droughts than are cash crops with shallow roots, thus building the five livelihood capital assets.

The major livelihood benefits during both floods and drought were fruit for sale and consumption. Complementary to this research, work by Thorlakson and Neufeldt (2012) and Mbow et al. (2014) in Kenya supports the idea that agroforestry can provide an alternative source of food and income during floods and drought. These results support the idea of agroforestry as an alternative livelihood that is important during times of stress. Having agroforestry as a supporting livelihood that can still be used during floods and drought means that agroforestry can help build livelihood resilience by better preparing households to manage the effects of shocks, to navigate uncertainty, and to adapt to changing environmental conditions (Marschke and Berkes 2006, Ngigi et al. 2015). 


\section{Agroforestry and livelihood resilience}

According to Tanner et al. (2015), a resilient livelihood sustains well-being despite environmental, economic, social, and political disturbances. For some households, agroforestry can help build livelihood resilience to floods and drought. At best, this means that households are in part using agroforestry to adjust their livelihood activities to long-term changing conditions (Adger 2003, Mosberg and Eriksen 2015) with the aim of sustaining livelihood opportunities during drought and flood (Tanner et al. 2015). Allison and Ellis (2001) suggest that the most robust livelihood system is one displaying high resilience, and our research (particularly Table 4 and Fig. 5) illustrates how agroforestry can directly and indirectly mitigate the effects of floods and drought, contributing to a more robust livelihood system. Further, agroforestry was being used by some people to increase on-farm crop diversity, which can increase redundancy within the agricultural system (McCord et al. 2015). Redundancy means that a significant proportion of the diversity of plants could be lost on the farm without having a significant effect on farm production in the short term (Kindt et al. 2006, Dawson et al. 2013). Livelihood diversification is a critical method used to help people prepare for and adapt to change (Ellis 2000, Hodbod and Eakin 2015).

Agroforestry was very important for some households during flood, drought, and the 1997 El Niño event. Notably, agroforestry was most important for households with medium levels of financial capital. Wealthier households may have other financial resources to draw from such as outside employment, remittances, businesses, etc. (Serrat 2010), whereas those with lower financial capital may not have the resources to invest in agroforestry in the first place (Belsky 1993, Bewket 2005). This is important for development practitioners because it shows that agroforestry can be one activity helping middle-range income households adapt to floods and drought. If a development project aims to assist the most vulnerable lower income households, the project must focus not only on promoting agroforestry practices, but also on providing people with access to resources that help them invest properly in agroforestry (i.e., markets, irrigation, seeds, and other inputs). Thus, the finding that agroforestry is particularly important for middle-income households is potentially the most significant for the development and policy communities.

\section{CONCLUSION}

We aimed to answer the call for more comprehensive, empirical research exploring the relationships between agroforestry and livelihood resilience to floods and droughts. Results from two communities in Isiolo County, Kenya indicate that agroforestry can and does build livelihood resilience to floods and drought. First, perceptions of drought may be influenced by practicing agroforestry. Second, agroforestry provides livelihood and environmental benefits during both flood and drought events. Lastly, agroforestry helps directly and indirectly build livelihood resilience to floods and droughts. Our work also highlights the use of the sustainable livelihoods approach to conceptualize and measure livelihood resilience, which may prove useful for academic or development practitioners aiming to measure livelihood resilience.

Our research identifies specific ways that farmers are integrating trees into their agricultural systems, many of whom are purposefully doing this to help their households prepare for future floods or drought. These results provide specific examples of how agroforestry can build livelihood resilience, which could be incorporated into resilience-building development projects. Policies and development projects that replicate or scale up these results could have significant and beneficial effects for communities that are struggling to adapt to increasing floods and drought. As stated by Maathai (2012:4-5), it is "more important than ever before to redouble our efforts to protect the environment... and provide smallholder farmers with sustainable ways of increasing their production and meeting their livelihood needs." Identifying potential strategies to build livelihood resilience to the effects of climate change is particularly crucial for smallholder farmers; according to our research, agroforestry may be one promising option. As noted by a female farmer in Burat, "We decided to plant trees because they do not dry up fast during times of drought... these times it helps us, the times when there is no rain, it helps us. If you water it a little bit, it produces fruit and you eat."

Responses to this article can be read online at: http://www.ecologyandsociety.org/issues/responses. $\mathrm{php} / 9461$

\begin{abstract}
Acknowledgments:
Most importantly, we acknowledge the communities of Burat and Kinna, who so graciously welcomed us, and the households who spent hours answering our endless questions. This research would not have been possible without the assistance of the CGIAR research program on Climate Change, Agriculture and Food Security; the World Agroforestry Centre in Nairobi; and the Kenya Red Cross Society - Isiolo Branch, in Isiolo. Red Cross volunteers played an integral role in all stages of data collection, and special thanks go to Noor Hussein. We also thank Joel Harrter, Lisa Dilling, Myles Osborne, and Max Boykoff for their feedback on research instruments. Much gratitude also goes to the University of Colorado Boulder. Funding: This work was supported by a U.S. Borlaug Fellows in Global Food Security Graduate Research Grant (\#206766), which supported field and research costs for A. Quandt. Publication of this article was funded by the University of Colorado Boulder Libraries Open Access Fund.
\end{abstract}

\section{LITERATURE CITED}

Adato, M., and R. Meizen-Dick. 2002. Assessing the impact of agricultural research on poverty using the sustainable livelihoods framework. FCND Discussion Paper 128, EPTD Discussion Paper 89. International Food Policy Research Institute, Washington, D.C., USA. [online] URL: http://ebrary.ifpri.org/ $\mathrm{cdm} / \mathrm{ref} / \mathrm{collection} / \mathrm{p} 15738 \mathrm{coll} / \mathrm{id} / 71441$

Adger, W. N. 2003. Social capital, collective action, and adaptation to climate change. Economic Geography 79 (4):387-404. http://dx.doi.org/10.1111/j.1944-8287.2003.tb00220. $\underline{x}$

Agresti, A., and B. Finlay. 2009. Statistical methods for the social sciences. Fourth edition. Pearson Education, Essex, UK. 
Allison, E. H., and F. Ellis. 2001. The livelihoods approach and management of small-scale fisheries. Marine Policy 25 (5):377-388. http://dx.doi.org/10.1016/S0308-597X(01)00023-9

Belsky, J. 1993. Household food security, farm trees, and agroforestry: a comparative study in Indonesia and the Philippines. Human Organization 52(2):130-141. http://dx.doi. org/10.17730/humo.52.2.308kw181875xpt0r

Berkes, F., J. Colding, and C. Folke, editors. 2002. Navigating social-ecological systems: building resilience for complexity and change. Cambridge University Press, Cambridge, UK. http://dx. doi.org/10.1017/CBO9780511541957

Bernard, H. R. 2011. Research methods in anthropology: qualitative and quantitative approaches. Fifth edition. AltaMira, Lanham, Maryland, USA.

Bewket, W. 2005. Biofuel consumption, household level tree planting and its implications for environmental management in the northwestern highlands of Ethiopia. Eastern Africa Social Science Research Review 21(1):19-38.

Boye, S. R., and R. Kaarhus. 2011. Competing claims and contested boundaries: legitimating land rights in Isiolo District, northern Kenya. Africa Spectrum 46(2):99-124. [online] URL: http://journals.giga-hamburg.de/index.php/afsp/article/view/812/0

Brandt, S. A., A. Spring, C. Hiebsch, J. T. McCabe, E. Tabogie, M. Diro, G. Wolde-Michael, G. Yntiso, M. Shigeta, and S. Tesfaye. 1997. The "tree against hunger" Enset-based agricultural systems in Ethiopia. American Association for the Advancement of Science, Washington, D.C., USA. [online] URL: http://www. clas.ufl.edu/users/aspring/publications/enset.pdf

Brown, K. 2014. Global environmental change I: a social turn for resilience? Progress in Human Geography 38(1):107-117. https:// doi.org/10.1177/0309132513498837

Bryan, E., C. Ringler, B. Okoba, C. Roncoli, S. Silvestri, and M. Herrero. 2013. Adapting agriculture to climate change in Kenya: household strategies and determinants. Journal of Environmental Management 114:26-35. http://dx.doi.org/10.1016/j.jenvman.2012.10.036

Campbell, B., J. A. Sayer, P. Frost, S. Vermeulen, M. Ruiz Pérez, A. Cunningham, and R. Prabhu. 2001. Assessing the performance of natural resource systems. Conservation Ecology 5(2):22. [online] URL: http://www.consecol.org/vol5/iss2/art22/

Carney, D. 1998. Sustainable rural livelihoods: What contribution can we make? Department for International Development, London, UK.

Carpenter, S., B. Walker, J. M. Anderies, and N. Abel. 2001. From metaphor to measurement: resilience of what to what? Ecosystems 4(8):765-781. http://dx.doi.org/10.1007/s10021-001-0045-9

Chambers, R., and G. R. Conway. 1992. Sustainable rural livelihoods: practical concepts for the 21st century. IDS Discussion Paper 296. Institute of Development Studies, Brighton, UK. [online] URL: http://www.ids.ac.uk/publication/sustainablerural-livelihoods-practical-concepts-for-the-21st-century

Cooper, S. J., and T. Wheeler. 2015. Adaptive governance: livelihood innovation for climate resilience in Uganda. Geoforum 65:96-107. http://dx.doi.org/10.1016/j.geoforum.2015.07.015
Dawson, I. K., M. R. Guariguata, J. Loo, J. C. Weber, A. Lengkeek, D. Bush, J. Cornelius, L. Guarino, R. Kindt, C. Orwa, J. Russell, and R. Jamnadass. 2013. What is the relevance of smallholders' agroforestry systems for conserving tropical tree species and genetic diversity in circa situm, in situ and ex situ settings? A review. Biodiversity and Conservation 22(2):301-324. http://dx.doi.org/10.1007/s10531-012-0429-5

Elasha, B. O., N. G. Elhassan, H. Ahmed, and S. Zakieldin. 2005. Sustainable livelihood approach for assessing community resilience to climate change: case studies from Sudan. AIACC Working Paper 17. Assessments of Impacts and Adaptations of Climate Change (AIACC), International START Secretariat, Washington, D.C., USA. [online] URL: http://www.start.org/Projects/AIACC Project/ working papers/Working\%20Papers/AIACC WP No017.pdf

Ellis, F. 2000. Rural livelihoods and diversity in developing countries. Oxford University Press, Oxford, UK.

Enns, C., and B. Bersaglio. 2015. Exploring the implications of oil and gas development for livelihood resilience in Turkana, Kenya. For the PRISE small grant programme of the Overseas Development Institute. Overseas Development Institute, London, UK. [online] URL: http://www.academia.edu/13047117/ Exploring the implications_of_oil_and gas development_for_livelihood resilience in Turkana Kenya

Erenstein, O., J. Hellin, and P. Chandna. 2010. Poverty mapping based on livelihood assets: a meso-level application in the IndoGangetic Plains, India. Applied Geography 30(1):112-125. http:// dx.doi.org/10.1016/j.apgeog.2009.05.001

Franzel, S., and S. J. Scherr, editors. 2002. Trees on the farm: assessing the adoption potential of agroforestry practices in Africa. CABI, Wallingford, UK. http://dx.doi.org/10.1079/9780851995618.0000

Funk, C., G. Eilerts, F. Davenport, and J. Michaelsen. 2010. A climate trend analysis of Kenya-August 2010. Fact Sheet 2010-3074. U.S. Geological Survey, Sioux Falls, South Dakota, USA. [online] URL: https://pubs.usgs.gov/fs/2010/3074/

Garrity, D. P., F. K. Akinnifesi, O. C. Ajayi, S. G. Weldesemayat, J. G. Mowo, A. Kalinganire, M. Larwanou, and J. Bayala. 2010. Evergreen agriculture: a robust approach to sustainable food security in Africa. Food Security 2(3):197-214. http://dx.doi. org/10.1007/s12571-010-0070-7

Helland, J. 1998. Institutional erosion in the drylands: the case of the Borana pastoralist. Eastern Africa Social Science Research Review 14(2):49-71.

Hodbod, J., and H. Eakin. 2015. Adapting a social-ecological resilience framework for food systems. Journal of Environmental Studies and Science 5(3):474-484. http://dx.doi.org/10.1007/ s13412-015-0280-6

Hogg, R. 1983. Re-stocking the Isiolo Boran: an approach to destitution among pastoralists. Nomadic Peoples 14:35-39.

Hogg, R. 1989. The politics of changing property rights among Isiolo Boran pastoralists in northern Kenya. Pages 20-31 in P. T. W. Baxter and R. Hogg, editors. Property, poverty and people: changing rights in property and problems of pastoral development. Department of Social Anthropology and International Development Centre, University of Manchester, Manchester, UK. 
Holling, C. S. 1973. Resilience and stability of ecological systems. Annual Review of Ecology and Systematics 4:1-23. http://dx.doi. org/10.1146/annurev.es.04.110173.000245

Jillo, A., A. A. Aboud, and D. L. Coppock. 2006. From herd diversification to livelihood diversification as a response to poverty: the case of the Waso Boran of northern Kenya. Research Brief 06-05-PARIMA. Global Livestock Collaborative Research Support Program, University of California, Davis, California, USA.

Jones, L., and T. Tanner. 2015. Measuring subjective resilience: using people's perceptions to quantify household resilience. Working Paper 423. Overseas Development Institute, London, UK. http://dx.doi.org/10.13140/RG.2.1.2438.1289

Kandji, S. T., L. V. Verchot, J. Mackensen, A. Boye, M. van Noordwijk, T. P. Tomich, C. Ong, A. Albrecht, and C. Palm. 2006. Opportunities for linking climate change adaptation and mitigation through agroforestry systems. Pages 113-122 in D. Garrity, A. Okono, M. Grayson, and S. Parrott, editors. World agroforestry into the future. World Agroforestry Centre, Nairobi, Kenya.

Kindt, R., P. Van Damme, A. J. Simons, and H. Beeckman. 2006. Planning tree species diversification in Kenya based on differences in tree species composition between farms. I. Analysis of tree uses. Agroforestry Systems 67(3):215-228.

Lebel, L., J. M. Anderies, B. Campbell, C. Folke, S. HatfieldDodds, T. P. Hughes, and J. Wilson. 2006. Governance and the capacity to manage resilience in regional social-ecological systems. Ecology and Society 11(1):19. [online] URL: http://www. ecologyandsociety.org/vol11/iss1/art19/

Leslie, P., and J. T. McCabe. 2013. Response diversity and resilience in social-ecological systems. Current Anthropology 54 (2):114-143. http://dx.doi.org/10.1086/669563

Lin, B. B. 2007. Agroforestry management as an adaptive strategy against potential microclimate extremes in coffee agriculture. Agriculture and Forest Meteorology 114(1-2):85-94. http://dx.doi. org/10.1016/j.agrformet.2006.12.009

Lin, B. B. 2011. Resilience in agriculture through crop diversification: adaptive management for environmental change. BioScience 61(3):183-193. http://dx.doi.org/10.1525/bio.2011.61.3.4

Maathai, W. 2012. Agroforestry, climate change, and habitat protection. Pages 3-6 in P. K. R. Nair and D. Garrity, editors. Agroforestry - the future of global land use. Springer, Dordrecht, The Netherlands. http://dx.doi.org/10.1007/978-94-007-4676-3_1

Marschke, M. J., and F. Berkes. 2006. Exploring strategies that build livelihood resilience: a case from Cambodia. Ecology and Society 11(1):42. http://dx.doi.org/10.5751/ES-01730-110142

Mbow, C., P. Smith, D. Skole, L. Duguma, and M. Bustamante. 2014. Achieving mitigation and adaptation to climate change through sustainable agroforestry practices in Africa. Current Opinion in Environmental Sustainability 6:8-14. http://dx.doi. org/10.1016/j.cosust.2013.09.002

McCord, P. F., M. Cox, M. Schmitt-Harsh, and T. Evans. 2015. Crop diversification as a smallholder livelihood strategy within semi-arid agricultural systems near Mount Kenya. Land Use Policy 42:738-750. http://dx.doi.org/10.1016/j.landusepol.2014.10.012
Meze-Hausken, E. 2004. Contrasting climate variability and meteorological drought with perceived drought and climate change in northern Ethiopia. Climate Research 27(1):19-31. http://dx.doi.org/10.3354/cr027019

Mosberg, M., and S. H. Eriksen. 2015. Responding to climate variability and change in dryland Kenya: the role of illicit coping strategies in the politics of adaptation. Global Environmental Change 35:545-557. http://dx.doi.org/10.1016/j.gloenvcha.2015.09.006

Nelson, V., and T. Stathers. 2009. Resilience, power, culture, and climate: a case study from semi-arid Tanzania, and new research directions. Gender and Development 17(1):81-94. http://dx.doi. org/10.1080/13552070802696946

Ngigi, M., U. Mueller, and R. Birner. 2015. The role of livestock portfolios and group-based approaches for building resilience in the face of accelerating climate change: an asset-based panel data analysis from rural Kenya. ZEF-Discussion Papers on Development Policy 205. Center for Development Research, Bonn, Germany. http://dx.doi.org/10.2139/ssrn.2676574

Noble, I. R., S. Huq, Y. A. Anokhin, J. Carmin, D. Goudou, F. P. Lansigan, B. Osman-Elasha, and A. Villamizar. 2014. Adaptation needs and options. Pages 833-868 in C. B. Field, V. R. Barros, D. J. Dokken, K. J. Mach, M. D. Mastrandrea, T. E. Bilir, M. Chatterjee, K. L. Ebi, Y. O. Estrada, R. C. Genova, B. Girma, E. S. Kissel, A. M. Levy, S. MacCracken, P. R. Mastrandrea, and L. L. White, editors. Climate change 2014: impacts, adaptation, and vulnerability. Part A: global and sectoral aspects. Contribution of Working Group II to the Fifth Assessment Report of the Intergovernmental Panel on Climate Change. Cambridge University Press, Cambridge, UK. [online] URL: http://www.ipcc.ch/report/ar5/wg2/

Otuoma, J., J. Kinyamario, W. Ekaya, M. Kshatriya, and M. Nyabenge. 2009. Effects of human-livestock-wildlife interactions on habitat in an eastern Kenya rangeland. African Journal of Ecology 47(4):567-573. http://dx.doi.org/10.1111/j.1365-2028.2008.01009. $\underline{\mathrm{X}}$

Philpott, S. M., B. B. Lin, S. Jha, and S. J. Brines. 2008. A multiscale assessment of hurricane impacts on agricultural landscapes based on land use and topographic features. Agriculture, Ecosystems and Environment 128(1-2):12-20. http://dx.doi. org/10.1016/j.agee.2008.04.016

Porter, J. R., L. Xie, A. J. Challinor, et al. 2014. Food security and food production systems. Pages 485-533 in C. B. Field, V. R. Barros, D. J. Dokken, K. J. Mach, M. D. Mastrandrea, T. E. Bilir, M. Chatterjee, K. L. Ebi, Y. O. Estrada, R. C. Genova, B. Girma, E. S. Kissel, A. M. Levy, S. MacCracken, P. R. Mastrandrea, and L. L. White, editors. Climate change 2014: impacts, adaptation, and vulnerability. Part A: global and sectoral aspects. Contribution of Working Group II to the Fifth Assessment Report of the Intergovernmental Panel on Climate Change. Cambridge University Press, Cambridge, UK. [online] URL: http://www. ipcc.ch/report/ar5/wg2/

Rakodi, C. 1999. A capital assets framework for analysing household livelihood strategies: implications for policy. Development Policy Review 17(3):315-342. http://dx.doi. org/10.1111/1467-7679.00090 
Rao, K. P. C., W. G. Ndegwa, K. Kizito, and A. Oyoo. 2011. Climate variability and change: farmer perceptions and understanding of intra-seasonal variability in rainfall and associated risk in semi-arid Kenya. Experimental Agriculture 47 (2):267-291. http://dx.doi.org/10.1017/S0014479710000918

Rocheleau, D. E., F. R. Weber, and A. Field-Juma. 1988. Agroforestry in dryland Africa. International Council for Research in Agroforestry, Nairobi, Kenya.

Schroth, G., G. A. B. da Fonseca, C. A. Harvey, C. Gascon, H. L. Vasconcelos, and A.-M. N. Izac, editors. 2004. Agroforestry and biodiversity conservation in tropical landscapes. Island Press, Washington, D.C., USA.

Serrat, O. 2010. The sustainable livelihoods approach. Asian Development Bank, Washington, D.C., USA.

Shaw, R. 2006. Community-based climate change adaptation in Vietnam: inter-linkages of environment, disaster, and human security. Pages 521-547 in S. Sonak, editor. Multiple dimensions of global environmental changes. TERI Publications, New Delhi, India. [online] URL: http://citeseerx.ist.psu.edu/viewdoc/ download?doi=10.1.1.475.8279\&rep=rep1\&type $=$ pdf

Simelton, E., B. Viet Dam, and D. Catacutan. 2015. Trees and agroforestry for coping with extreme weather events: experiences form northern and central Viet Nam. Agroforestry Systems 89 (6):1065-1082. http://dx.doi.org/10.1007/s10457-015-9835-5

Sinclair, F. L. 1999. A general classification of agroforestry practice. Agroforestry Systems 46(2):161-180.

Slegers, M. F. W. 2008. "If only it would rain": Farmers' perceptions of rainfall and drought in semi-arid central Tanzania. Journal of Arid Environments 72(11):2106-2123. http://dx.doi. org/10.1016/j.jaridenv.2008.06.011

Speranza, C. I. 2013. Buffer capacity: capturing a dimension of resilience to climate change in African smallholder agriculture. Regional Environmental Change 13(3):521-535. http://dx.doi. org/10.1007/s10113-012-0391-5

Tacoli, C. 1999. Understanding the opportunities and constraints for low-income groups in the peri-urban interface: the contribution of livelihood frameworks. Department for International Development, London, UK.

Tanner, T., D. Lewis, D. Wrathall, R. Bronen, N. Cradock-Henry, S. Huq, C. Lawless, R. Nawrotzki, V. Prasad, M. A. Rahman, R. Alaniz, K. King, K. McNamara, M. Nadiruzzaman, S. HenlyShepard, and F. Thomalla. 2015. Livelihood resilience in the face of climate change. Nature Climate Change 5:23-26. http://dx.doi. org/10.1038/nclimate2431

Thorlakson, T., and H. Neufeldt. 2012. Reducing subsistence farmers' vulnerability to climate change: evaluating the potential contributions of agroforestry in western Kenya. Agriculture and Food Security 1:15. http://dx.doi.org/10.1186/2048-7010-1-15

Thulstrup, A. W. 2015. Livelihood resilience and adaptive capacity: tracing changes in household access to capital in central Vietnam. World Development 74:352-362. http://dx.doi. org/10.1016/j.worlddev.2015.05.019
Verchot, L. V., M. Van Noordwijk, S. Kandji, T. Tomich, C. Ong, A. Albrecht, J. Mackensen, C. Bantilan, K. V. Anupama, and C. Palm. 2007. Climate change: linking adaptation and mitigation through agroforestry. Mitigation and Adaptation Strategies for Global Change 12(5):901-918. http://dx.doi.org/10.1007/ s11027-007-9105-6

Walker, B., S. Carpenter, J. Anderies, N. Abel, G. S. Cumming, M. Janssen, L. Lebel, J. Norberg, G. D. Peterson, and R. Pritchard. 2002. Resilience management in social-ecological systems: a working hypothesis for a participatory approach. Conservation Ecology 6(1):14. [online] URL: http://www. consecol.org/vol6/iss1/art14/

Walker, B., and D. Salt. 2006. Resilience thinking: sustaining ecosystems and people in a changing world. Island Press, Washington, D.C., USA.

Walsh-Dilley, M., W. Wolford, and J. McCarthy. 2016. Rights for resilience: food sovereignty, power, and resilience in development practice. Ecology and Society 21(1):11. http://dx.doi.org/10.5751/ ES-07981-210111

World Agroforestry Centre. 2017. Corporate strategy 2017-2026. World Agroforestry Centre, Nairobi, Kenya. [online] URL: $\underline{\text { http:// }}$ www.worldagroforestry.org/sites/default/files/users/admin/Strategy $\%$ 20Report 2017.pdf

Yin, R. K. 2013. Case study research: design and methods. Fifth edition. Sage, Thousand Oaks, California, USA. 